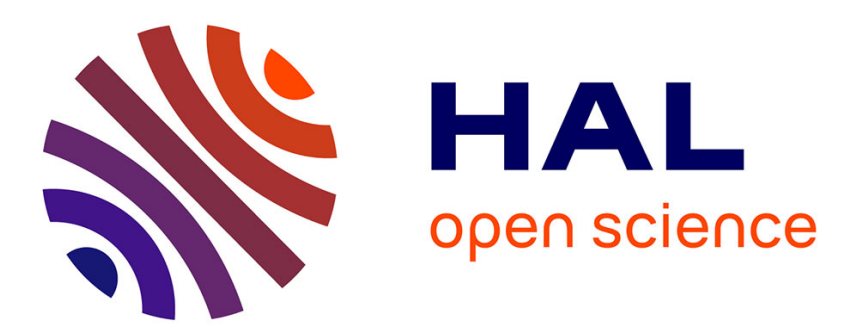

\title{
Comparison of statistical methods for determining risk of leakage from soil gas monitoring
}

Thomas Le Guenan, Jean-Charles Manceau, Frédérick Gal

\section{To cite this version:}

Thomas Le Guenan, Jean-Charles Manceau, Frédérick Gal. Comparison of statistical methods for determining risk of leakage from soil gas monitoring. GHGT-15 - 15th International Conference on Greenhouse Gas Control Technologies - Online, Mar 2021, Abu Dhabi - Online, United Arab Emirates. hal-02461504

\section{HAL Id: hal-02461504 https: / hal-brgm.archives-ouvertes.fr/hal-02461504}

Submitted on 30 Jan 2020

HAL is a multi-disciplinary open access archive for the deposit and dissemination of scientific research documents, whether they are published or not. The documents may come from teaching and research institutions in France or abroad, or from public or private research centers.
L'archive ouverte pluridisciplinaire HAL, est destinée au dépôt et à la diffusion de documents scientifiques de niveau recherche, publiés ou non, émanant des établissements d'enseignement et de recherche français ou étrangers, des laboratoires publics ou privés. 




$15^{\text {th }}$ International Conference on Greenhouse Gas Control Technologies GHGT-15

5 th $-8^{\text {th }}$ October 2020, Abu Dhabi, UAE

\title{
Comparison of statistical methods for determining risk of leakage from soil gas monitoring
}

\author{
Thomas Le Guénan ${ }^{a *}$, Jean-Charles Manceau ${ }^{a}$, Frederick Gal ${ }^{\mathrm{a}}$ \\ ${ }^{a}$ BRGM, 3 avenue C. Guillemin, BP 36009, 45060 Orléans Cedex 02, France
}

\begin{abstract}
Monitoring is one of the key activities in a thorough risk management framework, and it is particularly true in the context of underground carbon dioxide storage. The nature of the underground makes the state of the considered system both highly variable and uncertain. One challenge is thus to get a better understanding of the system evolution. Another challenge is to take robust decisions in presence of deep uncertainty. In particular, we explore in this work different ways for setting thresholds. Thresholds work as a decision-making aid: while a monitored indicator stays below a threshold, operation can continue as planned. When the indicator is over the threshold, the operator should consider mitigation actions. It is thus fundamental that thresholds are set in a robust manner in order to avoid false alarms or missed alarms. We can distinguish two broad types of monitoring data: the first type is expected to evolve with operations even under normal conditions, for instance the downhole pressure should increase when injecting $\mathrm{CO}_{2}$. On the other hand, the second type of data should not be evolving with operations under normal conditions. This is typically the case for environmental monitoring such as soil gas measurements. In this case, a baseline is needed before the beginning of operations, and the goal of monitoring is then to detect potential deviations from this baseline during operations. In this work, we focus on the second type of monitoring data. Our objective is to compare various methods for detecting deviations from the baseline, and to propose a method for a robust identification of such deviations. In this paper, we apply such methods on soil gas monitoring data, but the findings should be applicable to other types of data as well. The most basic method in this context is a visual comparison between baseline data and operations data. However, this method is subject to numerous biases and can often be impractical due to the quantity and complexity of data to deal with. A slightly better method is to set thresholds on a monitored parameter (e.g. $\mathrm{CO}_{2}$ concentration) and to define beforehand the course of action to follow in case the parameter goes outside the safe range. This method is sometimes refer to as a traffic light system when two thresholds are delimiting a safe green parameter range, an amber range and a red range. Even if popular, this method has a number of drawbacks, particularly if the monitored parameter is highly naturally variable, as is the case for soil $\mathrm{CO}_{2}$ concentrations. In several cases, variations of this method has led to false alarms potentially halting injection operations or even false allegations of leakage from external parties. Classical (or frequentists) statistical methods can help in better characterizing baselines, and in setting thresholds by computing the probability of false and missed alarms. Recently, some authors have also explored the use of Bayesian methods for characterizing baselines and using the results for setting "better" thresholds. One of the advantages of Bayesian methods is that the output is usually expressed in probabilities which allows for more informed thresholds and decisions. In addition to these methodological developments, various authors have
\end{abstract}

* Corresponding author. Tel.: +33238643853, E-mail address: t.leguenan@brgm.fr 
proposed alternative monitoring strategies in order to get a better signal for leakage, such as isotopes monitoring or co-monitoring of $\mathrm{O}_{2}$ and $\mathrm{CO}_{2}$ for a better representation of the underlying processes. However, these developments should also be guided by robust decision-making. We test the various methods on synthetic datasets as well as on a real dataset acquired over the course of several years of environmental monitoring in the context of the Rousse storage pilot located in South-West France and operated by Total between 2010 and 2013.

Keywords: Monitoring; Risk management; Thresholds; Soil gas; Decision-making; Uncertainty 